\title{
Karakterisik Morfologi Enam Isolat Lokal Trichoderma spp. dan Antagonismenya secara In Vitro terhadap Phytophthora palmivora
}

\author{
Jogeneis Patty ${ }^{1 *}$, Costanza Uruilal ${ }^{1}$, W. Rumahlewang ${ }^{1}$, A. Talahaturuson ${ }^{1}$ \\ ${ }^{1}$ Program studi Agroteknologi, Fakultas Pertanian, Universitas Pattimura \\ *Corresponding author: jognespatty@gmail.com
}

\begin{abstract}
Abstrak
Penelitian tentang isolat lokal Trichoderma spp. bertujuan untuk menemukan karakteristik morfologi enam isolat lokal Trichoderma dan mengkaji daya antagonismenya terhadap Phytohpthora palmivora sebagai patogen busuk buah dan kanker batang kakao. Karakterisitik enam isolat lokal Trichoderma spp. asal rizosfer tanaman memiliki karakteristik yang agak berbeda, baik bentuk dan warna koloninya, tetapi juga pertumbuhannya, serta karakteristik morfologinya yang dibedakan berdasarkan ukuran panjang konidiofor, panjang fialid dan diameter konidia. Lima isolat Trichoderma spp. memiliki daya antagonisme terhadap P. palmivora. Enam isolat memiliki daya antagonis terhadap patogen $P$. palmivora yakni TrichoRKT1, TrichoRKIT2, TrichoRPBS2, TrichoRK1S1, TrichoRKA2 dan TrichoRPK12. Presentase antagonisme terbesar juga terjadi pada isolat TRichoRKT1 (78,98\%) dan TrichoRPKT1 $(77,67 \%)$, keduanya tergolong antagonis kelas 2 atau aktifitas antagonis tinggi. Trichoderma spp. ditemukan memiliki mekanisme antagonisme kompetisi terhadap P. palmivora.
\end{abstract}

Kata kunci: Antagonisme, Phytohpthora palmivora, Trichoderma

\section{Abstract}

Research on local isolates of Trichoderma spp. this study aimed to find the morphological characteristics of six local isolates of Trichoderma and to study their antagonism against Phytohpthora palmivora as a pathogen of fruit rot and stem cancer of cocoa. Characteristics of six local isolates of Trichoderma spp. The origin of the plant rhizosphere has slightly different characteristics, both the shape and color of the colonies, but also the growth, as well as morphological characteristics which are distinguished by the length of the conidiophores, the length of the phialid and the diameter of the conidia. Five isolates of Trichoderma spp. have antagonism against $P$. palmivora. Six isolates had antagonistic activity against $P$. palmivora pathogens, namely TrichoRKT1, TrichoRKlT2, TrichoRPBS2, TrichoRKlS1, TrichoRKA2 and TrichoRPKl2. The greatest percentage of antagonism also occurred in isolates TRIchoRKT1 (78.98\%) and TrichoRPKT1 (77.67\%), both classified as class 2 antagonists or high antagonist activity. Trichoderma spp. found to have a mechanism of competitive antagonism against $P$. palmivora.

Keywords: Antagonism, Phytohpthora palmivora, Trichoderma 
Prosiding Seminar Nasional Pembangunan dan Pendidikan Vokasi Pertanian

Politeknik Pembangunan Pertanian Manokwari, 31 Juli 2021

e ISSN : 2774-1982

DOI : https://doi.org/10.47687/snppvp.v2i1.172

\section{PENDAHULUAN}

Trichoderma merupakan salah satu mikroflora di dalam tanah yang dapat berinteraksi di rizosfer tanaman. Jamur tersebut memiliki kemampuan yang sangan efektif, memungkinkan jamur ini tidak hanya berperan sebagai dekomposer, tetapi juga memberikan perlawanan atau antagonis terhadap jamur lain (Kubicek et al., 2011). Trichoderma spp. dapat diisolasi dari hampir semua jenis lahan pertanian, memiliki beberapa dampak positif ketika diaplikasikan dalam sistem budidaya tanaman, seperti sebagai agens pengendali hayati terhadap patogen tanaman, menginduksi resistensi sistemik tanaman, meningkatkan ketersediaan nutrisi dan penyerapan, promosi pertumbuhan tanaman, dan meningkatkan hasil panen (Harman, 2006). Untuk alasan tersebut, jamur ini sudah banyak dipelajari dan dipasarkan secara komersial sebagai fungisida hayati, pupuk hayati dan amandemen tanah (Vinale et al., 2008). Rizosfer adalah salah satu ekologi dari jamur Trichoderma spp. dan yang menarik adalah jamur tersebut dapat menghambat pertumbuhan jamur patogen di sekitar rizosfer tanaman (Druzhinina et al., 2011). Basil et al. (2019) telah menggunakan Trichoderma untuk perawatan benih, perlakuan bibit atau perlakuan tanah untuk mengendalikan jamur yang terbawa tanah seperti R. solani, Fusarium spp. dan Pythium spp. Jamur ini merupakan patogen tular tanah (Semangun, 2000). Patogen P. palmivora dan R. solani bertahan dalam dalam tanah sehingga sulit ditekan penyebarannya (Agrios, 2015; Smith et al., 2003 dalam Soenartiningsih et al., 2015).

Penggunaan fungisida untuk mengendalikan penyakit ini sangat terbatas dan berdampak negatif terhadap lingkungan. Keunggulan lain adalah sebagai agen pengendali hayati, aplikasinya dapat dilakukan melalui tanah secara langsung, melalui perlakuan benih maupun melalui kompos. Keuntungan dan keunggulan lain dari Trichoderma spp. adalah mudah dimonitor serta dapat tumbuh dan berkembang dengan cepat, sehingga keberadaannya di lingkungan dapat bertahan lama serta aman bagi lingkungan (Sutoyo, 2002 dalam Nahuwae, 2017). Penelitian ini bertujuan untuk menemukan karakteristik morfologi enam isolat lokal Trichoderma spp., antagonisme, dan mekanisme antagonismenya secara in vitro terhadap patogen busuk buah dan kanker batang kakao $P$. palmivora.

\section{METODE}

Penelitian ini dilakukan di Laboratorium Diagnosis Penyakit Tanaman Fakultas Pertanian dari bulan Juni sampai Agustus 2020. Tahapan penelitian terdiri dari 
Prosiding Seminar Nasional Pembangunan dan Pendidikan Vokasi Pertanian Politeknik Pembangunan Pertanian Manokwari, 31 Juli 2021

e ISSN : 2774-1982

DOI : https://doi.org/10.47687/snppvp.v2i1.172

pengambilan bahan tanaman sakit di desa Waipirit, Waesamu, dan Waimital kabupaten Seram Bagian Barat provinsi Maluku, isolasi dan pengamatan karakteristik koloni patogen, dan pengamatan mikroskopik patogen, subkultur antagonis, pengamatan karakteristik Trichoderma spp. pada media biakan, pengamatan mikroskopik terhadap konidiofor, fialid, dan konidia Trichoderma spp., perbanyakan koloni patogen dan antagonis, pengujian daya antagonismenya, dan pengamatan mekanisme antagonisme. Variabel yang diamati adalah presentase penghambatan jamur patogen $P$. palmivora oleh jamur antagonis Trichoderma spp. Kunci identifikasi yang digunakan adalah "Biodiversity of Trichoderma (Hypocreaceae) in Southem Europe and Macaronesia“ (Jaklitsch dan Voglrnayr, 2015), "Systematic of Hypocrea citrine and related taxa" (Barrie et al., 2006), "The Trichoderma koningii aggregate species" (Gary et al., 2006) dan "The Diversity Of Trichoderma spp. In South Africa" (Ihan, 2015).

Metode yang digunakan untuk menguji potensi isolat Trichoderma spp. sebagai antagonis terhadap patogen P. palmivora adalah Metode Biakan Ganda (Dual Culture Method) yang dikemukakan oleh Skidmore dan Dickson (1976) seperti terlihat pada Gambar 1.

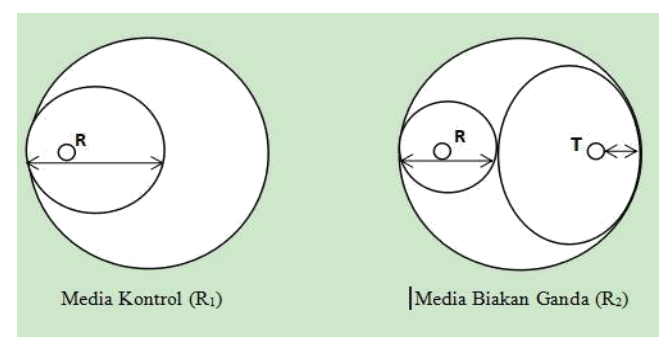

Gambar 1. Koloni patogen diletakan $2 \mathrm{~cm}$ dari pinggiran cawan petri sebagai biakan control; R1 = diameter koloni patogen pada biakan kontrol; R2 = diameter koloni patogen pada biakan ganda; $\mathrm{T}=$ koloni isolat Trichoderma spp. Diletakan $2 \mathrm{~cm}$ dari pinggiran cawan petri dan berhadapan dengan koloni $R$. solani.

Berdasarkan hasil pengamatan itu dapat dilakukan perhitungan persentase penghambatan $(\mathrm{PIRG}=$ Percentage Inhibition of Radial Growth) dengan menggunakan rumus yang dikemukakan oleh Skidmore dan Dickinson (1976) sebagai berikut:

$$
\text { PIRG }=\lcm{1-2100}
$$

PIRG $=$ Percentage Inhibition of Radial Growth

$\mathrm{R} 1=$ diameter koloni patogen pada biakan kontrol

$\mathrm{R} 2$ = diameter koloni patogen yang mengarah pada koloni antagonis 
Prosiding Seminar Nasional Pembangunan dan Pendidikan Vokasi Pertanian

Politeknik Pembangunan Pertanian Manokwari, 31 Juli 2021

e ISSN : 2774-1982

DOI : https://doi.org/10.47687/snppvp.v2i1.172

\section{HASIL DAN PEMBAHASAN}

\section{Karakteristik Morfologi Antagonis}

Keenam isolat Trichoderma spp. yang di subkultur pada media PDA rata-rata sudah terlihat terbentuknya miselium pada hari pertama setelah isolasi. Isolat TrichoRKA2, TrichoRK1BB 1, dan TrichoRKPK12 tumbuh lebih cepat dan memiliki ciri miselium yang lebih padat dibandingkan dengan miselium isolat lainnya dengan rata-rata diameter koloni 17-26 mm. Koloni isolat jamur Trichoderma spp. tumbuh memenuhi cawan petri pada hari keempat dengan miselium yang tampak lebih padat dan terbentuk cincin konsentris berwarna hijau putih yang khas dari isolat Trichoderma spp. lainnya. Miselium semua isolat Trichoderma spp. mengalami perubahan warna menjadi hijau seluruhnya pada permukaan media biakan, dan pada hari ketuju tampak pertumbuhan miselium jamur tersebut pada dinding cawan petri yang tidak ada alas medianya. Hasil pengamatan mikroskopik terhadap keenam isolat Trichoderma spp. menunjukan ciri konidiofor, fialid, dan konidia yang sama tetapi berbeda dalam bentuk dan ukurannya (Tabel 1).

Tabel 1. Karakteristik morfologi enam antagonis Trichoderma spp.

\begin{tabular}{|c|c|c|c|c|c|c|}
\hline $\begin{array}{l}\text { Trichoderma } \\
\text { Isolates }\end{array}$ & $\begin{array}{l}\text { Karakteristik } \\
\text { Konidiofor }\end{array}$ & $\begin{array}{l}\text { Karakteristik } \\
\text { Fialid }\end{array}$ & $\begin{array}{l}\text { Bentuk } \\
\text { Konidia }\end{array}$ & $\begin{array}{l}\text { Panjang } \\
\text { Konidiofor } \\
(\mu \mathrm{m})\end{array}$ & $\begin{array}{l}\text { Diameter } \\
\text { Konidia } \\
(\mu \mathrm{m})\end{array}$ & $\begin{array}{l}\text { Panjang } \\
\text { Fialid } \\
(\mu \mathrm{m})\end{array}$ \\
\hline TrichoRKTh & $\begin{array}{l}\text { Percabangan } \\
\text { panjang } \\
\text { verticilate }\end{array}$ & $\begin{array}{l}\text { Frequently, } \\
\text { paired }\end{array}$ & Elipsoidal & $42,51-59,73$ & $1,42-1,68$ & $8,42-8,70$ \\
\hline TichoRKIT & $\begin{array}{l}\text { Panjang, } \\
\text { percabangan } \\
\text { sedikit }\end{array}$ & $\begin{array}{l}\text { Frequently, } \\
\text { paired }\end{array}$ & $\begin{array}{l}\text { Globose } \\
\text { to } \\
\text { elipsoidal }\end{array}$ & $39,46-52,37$ & $2,14-2,59$ & $7,59-7,42$ \\
\hline TrichoRPBS 2 & $\begin{array}{l}\text { Percabangan } \\
\text { vertikal }\end{array}$ & $\begin{array}{l}\text { Phialidmore } \\
\text { elonged }\end{array}$ & $\begin{array}{l}\text { Sub } \\
\text { sylindrical } \\
\text { to narrow } \\
\text { elipsoidal }\end{array}$ & $23,67-38,73$ & $2,89-3,27$ & $8,46-8,80$ \\
\hline TrichoRKIS 1 & $\begin{array}{l}\text { Jarang } \\
\text { percabangan }\end{array}$ & $\begin{array}{l}\text { Slightly } \\
\text { inflated }\end{array}$ & Globose & $32,20-47,52$ & $2,51-2,89$ & $10,14-10,28$ \\
\hline TrichoRKA2 & $\begin{array}{l}\text { Jarang } \\
\text { percabangan }\end{array}$ & Lageniform & Obvoid & $20,69-39,71$ & $1,69-1,94$ & $9,23-9,76$ \\
\hline TrichoRPK & $\begin{array}{l}\text { Percabangan } \\
\text { vertical dan } \\
\text { banyak }\end{array}$ & $\begin{array}{l}\text { Frequently } \\
\text { paired, } \\
\text { lageniform, } \\
\text { convergen }\end{array}$ & Elipsoidal & $35,24-58,67$ & $2,76-3,15$ & $8,75-8,90$ \\
\hline
\end{tabular}


Prosiding Seminar Nasional Pembangunan dan Pendidikan Vokasi Pertanian Politeknik Pembangunan Pertanian Manokwari, 31 Juli 2021

e ISSN : 2774-1982

DOI : https://doi.org/10.47687/snppvp.v2i1.172

Isolat TrichoRKT1 memiliki konidiofor yang lebih panjang yakni 42,51 59,73 $\mu \mathrm{m}$ dan TrichoRKIT1 39,46 - 52,37 $\mu \mathrm{m}$, dibandingkan dengan ukuran konidiofor keempat isolat lainnya, dan isolat TrichoRKA2 memiliki ukuran terkecil yaitu 20,69 - 39,71 $\mu \mathrm{m}$. Isolat TrichoRPBS2 mempunyai ukuran diameter konidia lebih besar yakni 2,89 - 3,27 $\mu$ m, kemudian diikuti oleh isolat TrichoRPK1 2,76 3,15 $\mu \mathrm{m}$, dibandingkan dengan keempat isolat lainnya, sedangkan ukuran diameter konidia terkecil dimiliki oleh isolat TrichoRKT1 1,42 - 1,68 $\mu \mathrm{m}$. Isolat TrichoRKIS1 mempunyai ukuran fialid yang lebih panjang yaitu 10,14 - 10,28 $\mu \mathrm{m}$, kemudian diikuti oleh TrichoRKA2 9,23 - 9,76 $\mu \mathrm{m}$, dibandingkan dengan keempat isolat lainnya, dan ukuran fialid terkecil dimiliki oleh isolat TrichoRPBS2 8,46 8,80 $\mu \mathrm{m}$.

\section{Antagonisme Trichoderma spp. terhadap P.palmivora}

Antagonisme keenam isolat Trichoderma spp. terhadap patogen busuk buah kakao P. palmivora juga terlihat pada hari kedua setelah konfrontasi pada media kultur ganda (H2-SK), ketiga (H3-SK), keempat (H4-SK), kelima (H5-SK), keenam (H6-SK), dan hari ketujuah (H7-SK). Persentase daya hambat atau antagonisme terhadap patogen $P$. palmivora oleh isolat TrichoRKT1 (4,30\%) dan TrichoRKA2 (4,12\%), persentase daya hambatnya tidak jauh berbeda dengan keempat isolat lainnya, masing-masing TrichoRKIT(3,97\%), TrichoRKIS1 (3,72\%), TrichoRKA2 (3,25\%), TrichoRPBS2 $(3,20 \%)$.

Persentase antagonisme berkisar dari 3,20\% (TrichoRPBS2) sampai 4,30\% (TrichoRKT1). Daya antagonismenya meningkat sampai dengan hari ketujuh, dan terindikasi bahwa isolat TrichoRKT1 memiliki nilai daya antagonisme yang lebih besar (78,98\%), kemudian diikuti oleh isolat TrichoRPK1 (77,26\%), dibandingkan dengan keempat isolat lainnya tetapi persentasenya tidak jauh berbeda, masing-masing TrichoRKIT (76,03\%), TrichoRKIS1 (75,25\%), TrichoRKA2 (74,11\%), dan TrichoPBS2 $(73,06 \%)$.

Antagonisme yang terjadi pada keenam isolat Trichoderma spp. terhadap patogen busuk buah dan kanker batang kakao menunjukan adanya penghambatan. Persentase antagonisme tertinggi terjadi pada isolat TrichoRKT1 memiliki nilai daya antagonisme yang lebih besar (78,98\%), kemudian diikuti oleh isolat TrichoRPK1 (77,26\%), dibandingkan dengan keempat isolat lainnya tetapi persentasenya tidak jauh berbeda, masing-masing TrichoRKIT (76,03\%), TrichoRKIS1 (75,25\%), TrichoRKA2 (74,11\%), dan TrichoPBS2 (73,06\%). 
Prosiding Seminar Nasional Pembangunan dan Pendidikan Vokasi Pertanian Politeknik Pembangunan Pertanian Manokwari, 31 Juli 2021

e ISSN : 2774-1982

DOI : https://doi.org/10.47687/snppvp.v2i1.172

Daya antagonisme keenam isolat Trichoderma spp. terhadap patogen busuk buah kakao $P$. palmivora mulai terlihat pada hari kedua setelah konfrontasi pada media kultur ganda (Gambar 2).

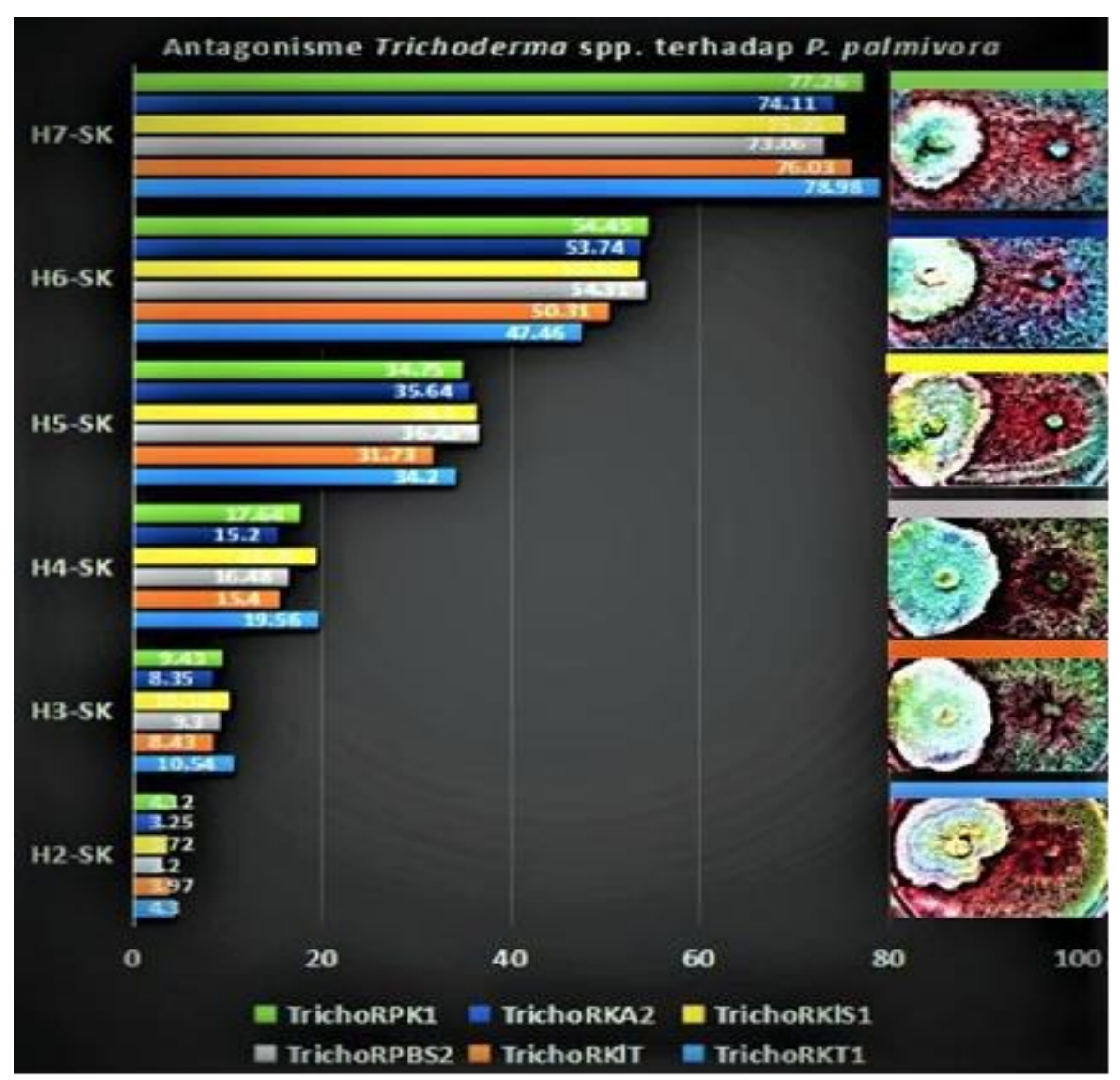

Gambar 2. Antagonisme 6 isolat Trichoderma spp. terhadap P. palmivora secara in vitro pada biakan ganda, umur biakan hari ke-2 setelah konfrontasi (H2SK), ke-3 (H3-SK), ke-4 (H4-SK), ke-5 (H5-SK), ke-6 (H6-SK), dan hari ke-7 (H7-SK).

Berdasarkan kriteria antagonisme yang dikemukakan oleh Bella et al. (1982), kedua isolat Trichoderma spp. tersebut tergolong antagonis kelas 2, yakni jamur antagonis tumbuh agak cepat dan menutupi seluruh permukaan media, sedangkan menurut Soy Tong (1988) keduanya tergolong aktifitas antagonisme tinggi. Persentase penghambatan yang besar dan pertumbuhan yang cepat dapat disebabkan karena isolat Trichoderma spp. yang diuji diduga memiliki seperangkat enzim seperti yang dimiliki oleh spesies Trichoderma lainnya seperti yang dikemukakan oleh Elad et al. (1982) dalam Soesanto et al. (2013), bahwa $T$. harzianum mensekresikan enzim $\beta$-3-glukanase dan kitinase pada dinding sel patogen Sclerotium rolfsii sebagai sumber karbon utamanya. Lebih lanjut dikemukakan, 
Prosiding Seminar Nasional Pembangunan dan Pendidikan Vokasi Pertanian

Politeknik Pembangunan Pertanian Manokwari, 31 Juli 2021

e ISSN : 2774-1982

DOI : https://doi.org/10.47687/snppvp.v2i1.172

bahwa aktivitas enzim lipase dan kitinase ditemukan ketika antagonis menyerang miselium S. rofsii. Selain itu, T. harzianum juga mengeluarkan enzim hidrolisis yang berbeda ketika menyerang miselium jamur patogen S. rolfsii, Rhizoctonia solani, dan Pythium aphanidermatum di dalam tanah. Menurut Reino et al. (2008), Trichoderma spp. yang diuji daya hambatnya terhadap jamur patogen secara in vitro, dapat memproduksi metabolit sekunder yang mudah menguap dan tidak mudah menguap seperti mikotoxin. Thiago et al. (2013) mengemukakan bahwa sebagian besar Trichoderma spesies dapat memproduksi metabolit yang bersifat toksik dan muda menguap dan berpengaruh terhadap pertumbuhan dan perkembangan jamur patogen tanaman.

Perkembangan penghambatan patogen busuk buah dan kanker batang kakao oleh isolat Trichoderma spp. menunjukan bahwa keenam isolat tersebut memiliki daya antagonis, yang dinilai berdasarakan presentase penghambatan pada hari ke-2 sampai ke7. Berdasarkan pengamatan pada media biakan ganda, terlihat bahwa pertumbuhan koloni dari semua isolat Trichoderma spp. yang diuji lebih cepat terjadi dan menutupi koloni jamur $P$. palmivora. Ini menandakan bahwa Trichoderma spp. telah melakukan perlawanan terhadap $P$. palmivora, karena kemampuannya sebagai antagonis untuk menghambat pertumbuhan patogen tersebut. Terhambatnya pertumbuhan koloni $P$. palmivora diindikasikan dengan perubahan warna koloni dari putih menjadi kecoklatan yang dapat diamati dari sisi bawah cawan petri.

Penghambatan oleh isolat Trichoderma spp. secara in vitro belum tentu sama kemampuannya ketika berada di lapangan mengingat pengaruh faktor lingkungan, oleh karena itu akan dilakukan pengujian langsung terhadap tanaman di rumah kaca maupun di lapangan, guna memastikan kemampuannya, bukan saja sebagai agens pengendali hayati patogen tanaman, tetapi juga perannya dalam meningkatkan ketahanan tanaman dan memacu pertumbuhan tanaman.

\section{Mekanisme Antagonisme Trichoderma spp. terhadap P. palmivora}

Keenam isolat Trchoderma spp. dalam melakukan proses penghambatan atau antagonisme terhadap penyebab penyakit busuk buah dan kanker batang kakao $P$. palmivora, teramati secara in vitro memiliki kemampuan kompetisi yakni bersaing dengan P. palmivora dalam memperoleh nutrisi pada media biakan ganda. Hal ini diindikasikan dengan petumbuhan Trichoderma spp. menutupi permukaan koloni $P$. palmivora, rata-rata terjadi pada hari keempat setelah dikonfrontasi, bahkan pada hari ketujuh terlihat pertumbuhan miselium pada dinding cawan petri yang tidak memiliki alas media. 
Prosiding Seminar Nasional Pembangunan dan Pendidikan Vokasi Pertanian

Politeknik Pembangunan Pertanian Manokwari, 31 Juli 2021

e ISSN : 2774-1982

DOI : https://doi.org/10.47687/snppvp.v2i1.172

\section{KESIMPULAN}

Enam isolat lokal Trichoderma spp. memiliki karakteristik morfologi yang agak berbeda satu dengan lainnya, berdasarkan karakter dan ukuran konidiofor, karakter dan ukuran fialid, serta bentuk dan diameter konidia. Enam isolat tersebut yakni TrichoRKT1, TrichoRKIT2, TrichoRPBS2, TrichoRK1S1, TrichoRKA2 dan TrichoRPK12 memiliki daya antagonisme secara in vitro terhadap P. palmivora, patogen busuk buah dan kanker batang kakao persentase antagonisme terbesar terjadi pada isolat TRichoRKT1 $(78,98 \%)$ dan TrichoRPKT1 $(77,67 \%)$ terhadap keduanya tergolong antagonis kelas 2 atau aktifitas antagonis tinggi. Keenam isolat Trichoderma spp. ditemukan memiliki mekanisme antagonisme kompetisi terhadap P. palmivora, penyebab penyakit busuk buah dan kanker batang kakao.

\section{DAFTAR PUSTAKA}

Agrios, G.N. (2004). Plant Pathology, Departemen of Plant Pathology University of Florida, Elsevier Academic Press, Oxford, 948p, 2004.

Basil, Y., Mahde, Mohammed, A., Fayyadh, \& S.S. Al-Luaibi. (2019). Evaluation of Biofungicide Formulation of Trichoderma longibrachiatum in Controlling of Tomato Seedling Damping-off Caused by Rhizoctonia solani. ISSN 1814 - 5868 Basrah J. Agric. Sci., 32 (2) 135-149, 2019 E-ISSN: 2520-0860.

Bella, D.K, H.D. Wells., \& C.R. Markman. (1982). In vitro antago-nism of Trichoderma species against six fungal plant path-ogens, Phytopathology 72. 372-382, 1982.

Gary, J.S., et al. (2006). The Trichoderma koningii aggregate species, 2006.

Harman, G.E. (2016). Overview of mechanisms and uses of Trichoderma spp. Phytopathology 96, 190-194, 2016.

Intan, B., et al. (2013). Mekanisme Antagonisme Trichoderma spp. Terhadap Beberapa Patogen Tular Tanah. 32(2), 74-82.

Viterbo, A., Ramot, O., Chemin, L., \& Chet, I. (2002). Significance of lytic enzymes from Trichoderma spp. in the biocontrol of fungal plant pathogens. Anton Leeuw, Int J. 2002;81:549-556. doi: 10.1023/A:1020553421740.

Qualhato, T.F., Lopes, F.A.C., Steindorff, A.S., Brandão, R.S., Jesuino, R.S.A., \& Ulhoa C.J. (2013). Mycoparasitism studies of Trichoderma species against three phytopathogenic fungi: evaluation of antagonism and hydrolytic enzymeproduction. Biotechnol Lett. 2013;35:1461-1468. doi:10.1007/s10529013-1225-3.

Reino, J.L., Guerriero, R.F., Hernandez-Gala, R., \& Collado, I.G. (2008). Secondary metabolites from species of the biocontrol agent Trichoderma. Phytochem Rev 7:89-123, 2008. 
Prosiding Seminar Nasional Pembangunan dan Pendidikan Vokasi Pertanian

Politeknik Pembangunan Pertanian Manokwari, 31 Juli 2021

e ISSN : 2774-1982

DOI : https://doi.org/10.47687/snppvp.v2i1.172

Semangun, H. (2006). Penyakit-Penyakit Tanaman Hortikultura. Gadjah Mada Press, Yogyakarta, 808 p, 2006.

Skidmore, A.M. \& C.H. Dickinson. (1976). Colony interactions and hyphal interference between Septoria nodurum and phylloplane fungi. Trans. Br. Mycol. Soc. 66. pp: 57-64, 1976.

Stesya, N. (2017). Daya Hambat Sembilan Isolat Lokal Jamur Trichoderma spp. Secara In Vitro Terhadap Phytopthora palmivora Penyebab Penyakit Busuk Buah Kakao. Skripsi. fakultas Pertanian Universitas Pattimura Ambon, 2017.

Soenartiningsih, M.S., Pabbage, \& Nurasiah, D. (2011). Penggunaan Inokulum Antagonis (Trichoderma Dan Gliocladium) Dalam Menekan Penyakit Busuk Pelepah Pada Jagung. Balai Penelitian Tanaman Serealia.

Soernartiningsih, M.S., M. Akil, \& N.N. Anadayani. (2015). Cendawan Tular Tanah (Rhizoctonia solani) Penyebab Penyakit Busuk Pelepah pada Tanaman Jagung dan Sorgum dengan Komponen Pengendaliannya. Iptek tanaman Pangan, Vol 10. NO 2 .

Soesanto, L., Endang, M., Ruth, F.R., \& Ratna, S.D. (2013). Uji Kesesuaian Empat Isolat Trichoderma spp. dan daya hambat in vitro terhadap beberapa patogen tanaman. J. Tropika. ISSN 1411-7525 Vol. 13, No. 2: 117-123. 